
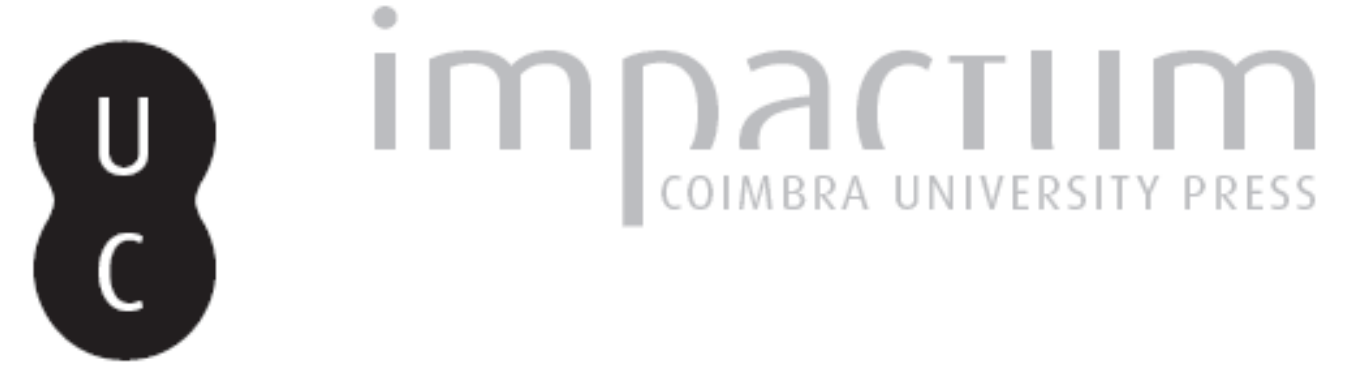

\title{
Lost and then found: the Mendes Correia collection of identified human skeletons curated at the University of Porto, Portugal
}

Autor(es): $\quad$ Cardoso, Hugo F. V.; Luísa, Marinho

Publicado por: Imprensa da Universidade de Coimbra

URL

persistente:

URI:http://hdl.handle.net/10316.2/42119

DOI:

DOI:https://doi.org/10.14195/2182-7982_32_2

Accessed : $\quad$ 26-Apr-2023 08:55:08

A navegação consulta e descarregamento dos títulos inseridos nas Bibliotecas Digitais UC Digitalis, UC Pombalina e UC Impactum, pressupõem a aceitação plena e sem reservas dos Termos e Condições de Uso destas Bibliotecas Digitais, disponíveis em https://digitalis.uc.pt/pt-pt/termos.

Conforme exposto nos referidos Termos e Condições de Uso, o descarregamento de títulos de acesso restrito requer uma licença válida de autorização devendo o utilizador aceder ao(s) documento(s) a partir de um endereço de IP da instituição detentora da supramencionada licença.

Ao utilizador é apenas permitido o descarregamento para uso pessoal, pelo que o emprego do(s) título(s) descarregado(s) para outro fim, designadamente comercial, carece de autorização do respetivo autor ou editor da obra.

Na medida em que todas as obras da UC Digitalis se encontram protegidas pelo Código do Direito de Autor e Direitos Conexos e demais legislação aplicável, toda a cópia, parcial ou total, deste documento, nos casos em que é legalmente admitida, deverá conter ou fazer-se acompanhar por este aviso.

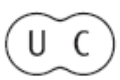




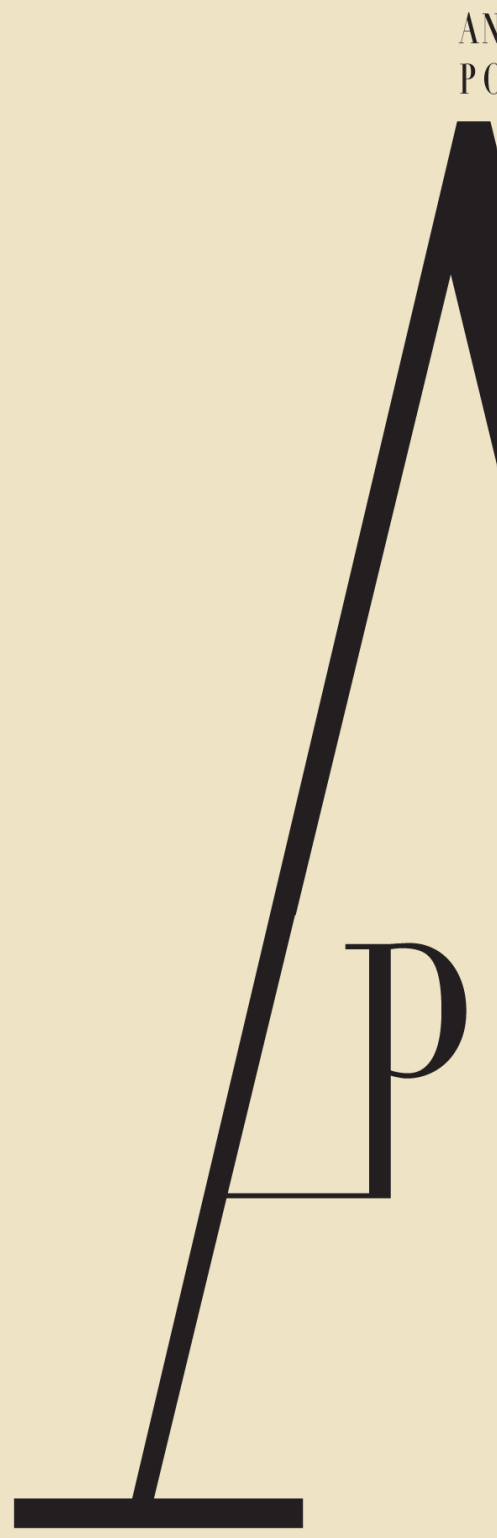

ANTROPOLOGIA

PORTUGUESA 


\title{
Lost and then found: the Mendes Correia collection of identified human skeletons curated at the University of Porto, Portugal
}

\section{Perdida e depois encontrada: Mendes Correia, a coleção de esqueletos humanos identificados da Universidade do Porto, Portugal.}

\author{
Hugo F. V. Cardoso ${ }^{1 *}$, Luísa Marinho ${ }^{1}$
}

\begin{abstract}
Among the several human skeletal reference collections that have been amassed in Portugal over the last 100 years or so, there is one that has remained in near anonymity for its almost entire existence. The collection was initiated by Dr. António Mendes Correia who collected abandoned skeletal remains from cemeteries of the city of Porto circa 1912-1917. Over the years, and for unknown reasons, its original documentation was lost and the collection has been treated as an unidentified assemblage of skeletons. Two previously unnoticed publications from the 1920's were found to have published basic biographic data for each individual in
\end{abstract}

Resumo De entre as várias coleções de esqueletos humanos identificados existentes em Portugal, uma tem permanecido num quase completo anonimato desde que foi constituída. Esta coleção foi iniciada pelo Dr. António Mendes Correia, que recolheu ossadas abandonadas de cemitérios do Porto por volta de 1912-1917. Ao longo do tempo, e por razões desconhecidas, a documentação original perdeu-se e coleção tem sido tratada, desde há muitos anos, como um conjunto de esqueletos não identificados. Recentemente foram localizadas duas publicações da década de 1920 que contêm dados biográficos sobre cada indivíduo da coleção, restituindo desta

\footnotetext{
1 Department of Archaeology and Centre for Forensic Research, Simon Fraser University, Burnaby, British Columbia, Canada.

*Corresponding author: hcardoso@sfu.ca
}

DOI: https://doi.org/10.14195/2182-7982_32_2 
the collection, thus restoring some of the lost information. The surviving specimens of the Mendes Correia collection are currently located at the Natural History Museum and at the Faculty of Sciences of the University of Porto. The collection is comprised of 99 individuals of known sex, age, and nativity, whose skeletons are found in various states of completeness. They represent a segment of the population of the city of Porto who were born throughout the 19th century. It is hoped that the information gathered and provided here can restore some of the lost research value of the Mendes Correia collection.

Keywords: Physical anthropology; skeletal biology; osteological series; reference collections; biographic records; conservation.

\section{Introduction}

Human skeletal reference collections play a key role in research and teaching in physical anthropology. Universities, museums and other institutions have been collecting archaeological and anatomical specimens for decades, but due to the unique nature of skeletal reference collections and the specific ways in which they have been amassed, they are relatively rare and are not widely available. A handful of these collections is now fairly well known (see, for example, Bedford et al., 1993; Hunt and Albanese, 2005; Komar and Grivas, 2008; Dayal et al., 2009; Passalacqua, 2009). Yet, several forma alguma da informação que havia sido perdida. O material remanescente da coleção Mendes Correia encontra-se atualmente no Museu de História Natural e na Faculdade de Ciências da Universidade do Porto. A coleção é composta por 99 indivíduos de sexo, idade e naturalidade conhecidos, e cujos esqueletos se encontram incompletos e em vários estados de conservação. Estes indivíduos representam um segmento da população da cidade do Porto nascida durante o século XIX. Espera-se que a informação reunida e aqui apresentada possa restituir o valor científico à coleção Mendes Correia.

Palavras-chave: Antropologia física; biologia do esqueleto; séries osteológicas; coleções de referência; registos biográficos; conservação.

other collections have more unnoticeable or relatively hidden existences, where only vague and/or imprecise information is known about them (see, for example, Usher, 2002). Others still exist in complete obscurity and even secrecy.

Portugal is probably unique in that it is perhaps uncommon that so many such collections have been amassed over the years in the country (Umbelino and Santos, 2011). The earliest collection, likely one of the earliest in Europe, is known as the Ferraz de Macedo Collection. This collection of over a thousand skulls and about 300 skeletons was amassed by a Lisbon physician between 1882 and 1889, and was donated in 1907 to the Natural 
History Museum in Lisbon (Ferreira, 1908; Cardoso, 2006a). Later, between the 1890s and the 1920s, similar collections were amassed at the institutes of anthropology of the University of Porto (Teixeira, 1964; Santos Júnior, 1969) and the University of Coimbra (Fernandes, 1985; Rocha, 1995). The Coimbra collections include one series of complete skeletons and several series of crania collected through a period of over 50 years (Rocha, 1995; Santos, 2000; Cunha and Wasterlain, 2007). In the 1970s, the Ferraz de Macedo Collection was almost completely destroyed by a fire, which prompted the amassing of a newer and even larger collection at the Natural History Museum in Lisbon. This new collection was initiated in the 1980s and was still incorporating specimens by 2003 , which resulted in more than 1800 skeletons collected over a period of about 30 years (Cardoso, 2006a; 2006b). More recently, since 2000 three other collections have been amassed at other institutions in Portugal. The earlier one is currently curated at the University of Évora (Anselmo and Fernandes, 2013), and the University of Coimbra added a new series of remains to its collections (Ferreira et al., 2014). The third collection was initiated under a research project lead by this paper's first author to obtain a new series of modern remains in Porto, as a result of a collaborative project between the Medical and Dental Schools at the University of Porto, the Northern
Delegation of the National Institute of Legal Medicine and Forensic Sciences, and other institutions. Common to all of these collections is that the skeletons they include originate from remains in abandoned burial plots at local cemeteries in Lisbon, Porto, Coimbra, Santarém and Évora. Rather than being destroyed and having their identity forever lost in communal graves, the universities were given permission to collect these remains and enhance their research and teaching outputs in skeletal biology and physical anthropology.

One of these earlier collections, however, has had an obscure existence for almost a century. This somewhat enigmatic series was amassed in the early 20th century by Dr. António Mendes Correia, founder and a central personality of the school of anthropology at the University of Porto. Little is known about the history or composition of the collection, as references to it have only been traced back to a couple of earlier publications (Correia, 1930; Santos Júnior, 1969). Although the collection was actually used in several of Mendes Correia's publications (Correia, 1917a; 1918a; 1918b; 1920a; 1920b; 1927) and in a handful of other studies published in Portuguese during the 1920s (Santos, 1924; Fernandes, 1925; Valença, 1925; Cunha, 1926), these remained in relatively obscurity and so did the collection. In fact, most of what is now known about the 
Mendes Correia Collection has probably circulated by word of mouth over the years. Even two recent studies, which either used materials from the collection (Marado, 2010) or provided a detailed historical account of Mendes Correia's contribution to Portuguese anthropology (Matos, 2012), could not provide further or more detailed information about its history and composition. The collection was known to be curated at the Natural History Museum (NHM) of the University of Porto through students who would visit the museum to study its archaeological collections. It was also thought to be comprised of only crania and mandibles as the recent study seemed to confirm (Marado, 2010).

In 2010, during the preparations for the research project that would initiate a new collection in Porto under the BoneMedLeg project (Marinho and Cardoso, 2012), we initiated a literature review of Mendes Correia's work. At about the same time, and in conversation with Maria José Cunha, curator of the Archaeology and Anthropology Section at the NHM, in Porto, we learned that skulls of the collection were curated at the Museum, but that there were no surviving records of it. For all purposes the collection was now being considered an unidentified series of skulls like many archaeological collections. The only surviving information referred to the sex of the individuals, which could be inferred from the labels written in their skulls. On the other hand, we had also learned that remnants of the collection and possibly its records or part of them could still be curated at the Faculty of Sciences of the University of Porto (FSUP). The Faculty had previously occupied the building which is now home to the $\mathrm{NHM}$, and many zoological and botanical collections were taken from the Museum when the Faculty moved to a new building in another part of the city. This prompted us to investigate in more detail whether the remaining of the Mendes Correia Collection could still be found and whether any records still existed.

The purpose of this paper is to briefly outline the historical context and background of the Mendes Correia Collection, and provide a detailed account of its composition. Although the original records of the collection are now considered lost, basic biographic information about each individual was possible to collect and collate for this investigation from previously unknown or unnoticed sources (Santos, 1924; Cunha, 1926), and is provided here in full.

\section{The (un)known history of the Mendes Correia Collection}

The earliest reference to the collection that we have found (Correia, 
1917b) suggests that it was originally stored at the Museum and Laboratory of Anthropology at the University of Porto. Mendes Correia's (1917b) publication was the first of a long series of osteometric studies ("Osteometria Portuguesa") that he conducted on the collection (Correia, 1917a; 1918a; 1918b; 1920a; 1920b; 1927). The Museum and Laboratory of Anthropology was created in 1912, under the recently established Faculty of Sciences at the University of Porto. Later, in 1923, the Museum and Laboratory was re-established as Institute of Anthropology under the leadership of Mendes Correia (Santos, 2012), who acted as the Institute's director between 1926 and 1958 (Matos, 2012). In 1996, the FSUP initiated a slow process of relocation to a new building in the city, and the Natural History Museum was created in the meantime (Cunha, 2012). At its genesis, the NHM kept most of the collections housed at the Institute of Anthropology, but also incorporated some collections from the Geology and Zoology Museums, which were separate museums under the FSUP at the time. Currently, the FSUP and the NHM are completely separate entities under the University of Porto, although the NHM occupies the space which was once that of the FSUP. Mendes Correia was responsible for incorporating several collections into the early Laboratory and Museum of Anthropologyand, in homage to his contribution, the Anthropology
Section of the NHM was named "Núcleo de Antropologia e Pré-História Mendes Corrêa". That same section of the NHM eventually became known simply as the Archaeology and Anthropology Section ("Núcleo de Arqueologia e Antropologia") (Cunha, 2012).

The Archaeology and Anthropology Section of the NHM currently holds several archaeological collections of human remains, plus a research ("coleção de estudo") and a teaching ("coleção de aulas") collection, both from contemporary sources. It is likely that both of these collections represent one single unit and thus comprise the series of identified human skeletons that Mendes Correia amassed, with elements or specimens stored for research purposes and others reserved for lab classes. Further information about the collection, however, is rare and scant in details. In 1917, Mendes Correia describes the acquisition of 40 documented skeletons obtained from one of the cemeteries in the city of Porto ("quarenta ossadas, provenientes de um dos cemitérios da cidade, o do Repouso, e acompanhadas das indicações de sexo, idade, naturalidade e profissão" [Correia, 1917b: 3]). On the other hand, according to the Notice Sommaire, an abstract submitted by Mendes Correia to the XV Congress Internationale d'Anthropologie et d'Archéologie Préhistorique, organized in Coimbra in 1930, the collection was comprised of 173 crania (125 were 
documented), 41 documented skeletons, and 400 isolated elements, including limb bones and mandibles (Correia, 1930). This is not entirely consistent with the 1917 publication, which describes 40 skeletons and not 41. The information provided in the abstract also suggests that more crania and possibly other elements were added to the collection. In a later publication, only Santos Júnior (1969) mentions very briefly that Mendes Correia had collected a series of skeletons from the various cemeteries in Porto ("série de esqueletos recolhidos em vários cemitérios do Porto" [Santos Júnior, 1969: 44]), but does not provide any further details.

It is very likely that the collection, as a whole, remained stored in the Institute of Anthropology until 1996, when it effectively became part of the NHM. As the FSUP relocated to a new building and the NHM was being created in its vacated space, Cunha (2012) believed that a significant portion of the Mendes Correia Collection had been moved from the NHM to the FSUP, to support the physical anthropology labs. The most recent inventory at the NHM counted only about 6 skulls, several long bones (Cunha, 2012) and 163 mandibles (Marado, 2010) from what seemed to be the Mendes Correia collection. Further to the dispersal of the collection, no written records or documentation about the collection have survived over the years.
This meant that the collection remained relatively unknown and inaccessible as a whole, for a relatively long period of time. It was not until recently that we became aware of a series of old publications that seemed to have remained unknown to or unnoticed by the wide Portuguese anthropology community. These old publications include four theses in medicine that were published between 1924 and 1926 (Santos, 1924; Fernandes, 1925; Valença, 1925; Cunha, 1926) on various craniometric aspects of the skeletal collections curated at the Faculty of Sciences (Laboratory and Museum of Anthropology) and at the Faculty of Medicine (Museum of Anatomy). In the dissertations by Santos (1924) and by Cunha (1926), the sex and the age of each individual in the collection are provided, and Santos (1924) adds information about place of birth. Access to these data meant that the biographic information about the skeletons in the Mendes Correia Collection could be recovered, at least partly, and its research potential restored. However, at this point in the research, most of the known materials of the collection were curated at the NHM and the whereabouts of the remaining materials was still uncertain.

In 2010, we contacted the FSUP to determine whether any skeletal material from the Mendes Correia reference collection had potentially been taken from the NHM to the FSUP, when 
it was relocated to a new building. At the FSUP, a large set of commingled skeletons, organized by bone type, was found (Figure 1). At this time, several of the crania and various long bones were being actively used in the physical anthropology labs. Notably, however, the majority of bones were found labelled with collection numbers (Figure 2). These numbers were contrasted to the known collection numbers, sex, and measurements of the cranium and of the long bones published for each individual in Fernandes (1925) and Correia (1927).
This confirmed these skeletons as being a significant component of the original collection of identified skulls and skeletons amassed by Mendes Correia sometime before 1917.

\section{The profile of the known (surviving) Mendes Correia Collection}

A total of 99 individuals were identified (Appendix 1) in this research, between specimens stored at the NHM

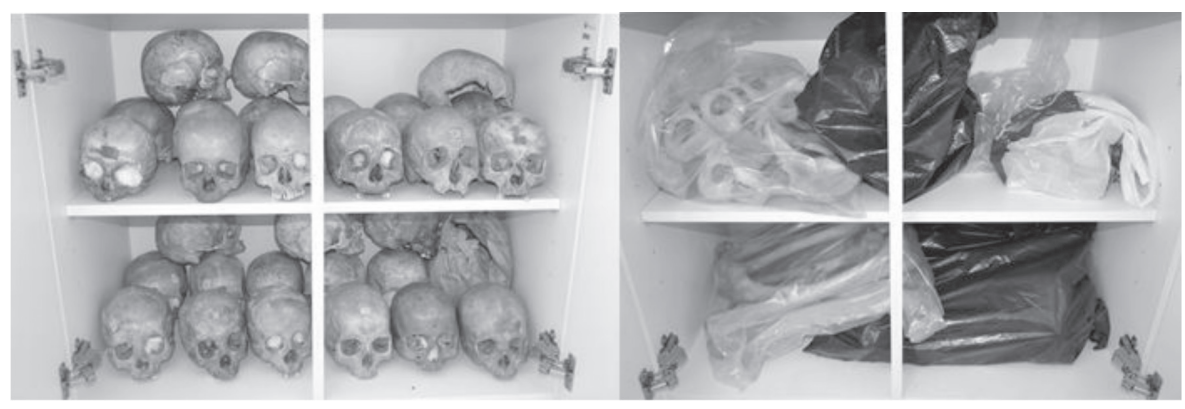

Figure 1. Storage of the remains organized by bone type, at FSUP. Non-human bones, unlabelled bones, and labelled bones not belonging to the Mendes Correia identified collection from cemeteries were found stored together.

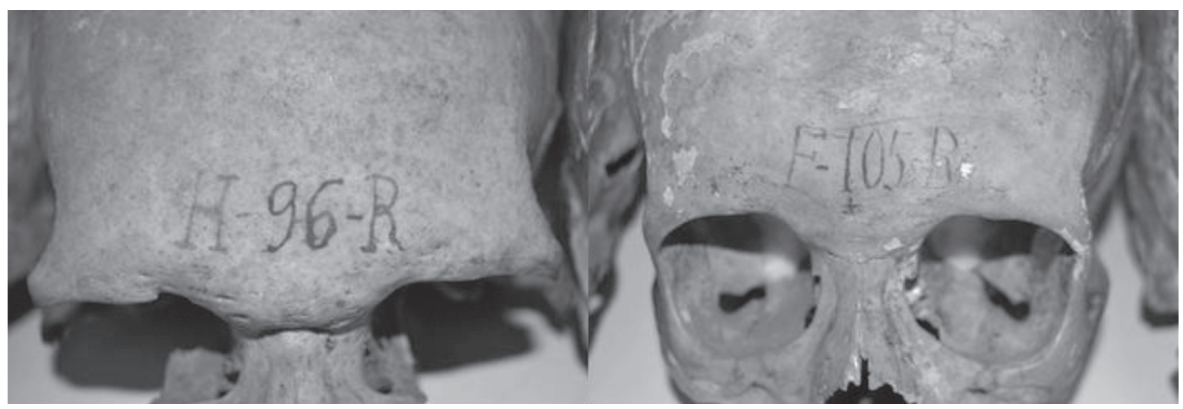

Figure 2. Labelled crania belonging to the Mendes Correia Collection, of a male individual with collection number 96 (H-96-R) and of a female individual with collection number 105 (F-105-R). 
and the FSUP. Information about the sex, age and nativity for each of these individuals was obtained from Santos (1924) and Cunha (1926), which is also provided in Appendix 1. A descriptive summary of the surviving collection by sex, age group and anatomical location can be found in Table 1 .

From the review of the labels in the different bones found in the Museum and the Faculty of Sciences, we have confirmed that bones from the same individual are presently located in both of these institutions. However, the large majority of both crania and postcranial elements are currently stored at the FSUP, and only the mandibles are almost exclusively found at the NHM. Among the bones identified as belonging to the collection amassed by Mendes Correia from cemeteries in Porto, we have also found non-human bones and unlabelled human bones.

The samples used by Santos (1924) and Cunha (1926), from which the biographic data was collected for this study, only included crania. Consequently, any other partial skeletons or individual bones that might have been collected from the cemeteries by Mendes Correia without an associated cranium are not included in the profile shown here and remain, therefore, unidentified. This explains, for example, why Marado (2010) reports that 163 mandibles are stored at the Museum, and we have only identified 39 of them (see Table 1), as these are the ones which either have or once had an associated cranium. Other labelled bones, including at least 6 crania, were found both at the NHM and at the FSUP but we could not find a match between the label and the collection numbers listed in Santos (1924) and Cunha (1926). These elements also remain unidentified. These unmatched cases refer to the blanks in the collection numbers listed in Appendix 1, which includes numbers 1 to 121 , but only 99 individuals are shown in total. It is likely that this material might have been once identified but, because it was excluded from the craniometric studies carried out by Santos (1924) and Cunha (1926), we no longer have access to their biographic information. It is also likely that material from this collection has been lost over the years given that only 56 of the 99 crania used by Santos (1924) and/or Cunha (1926) currently exist. These discrepancies also explain the disagreement between the existing number of specimens and the higher numbers of crania, skeletons, and isolated elements reported by Mendes Correia in the Notice Sommaire submitted to the XV Congress Internationale d'Anthropologie et d'Archéologie Préhistorique (Correia, 1930).

Although sex, age and nativity of the individuals in the collection could be obtained from Santos (1924) and Cunha (1926), no information could be retrieved about dates of death and/or 
birth for these individuals. Establishing a time frame for the collection is made even more difficult by the fact that there is no exact information about when the remains were actually collected from the cemeteries. We assume that most of the skeletons in the collection were collected anywhere prior to 1917, probably between 1912, when the Laboratory of Anthropology was created, and 1917, the year the earliest studies about the collection were published. Assuming that these remains originate from abandoned burials plots at the local cemeteries in Porto, a minimum period of 5 years must elapse between burial and exhumation of remains in abandoned plots. Consequently, the collection includes individuals who died prior to 1912 and likely much earlier. Considering the age range of the individuals in the collection (15-90 years, see Table 1), a likely range for years of birth is from 1822 to 1897 or earlier.

In his homage remarks to Mendes Correia, Santos Júnior (1969) refers that

Table 1. Descriptive summary of the 99 individuals belonging to the Mendes Correia collection with known sex and age (from Santos, 1924 and Cunha, 1926).

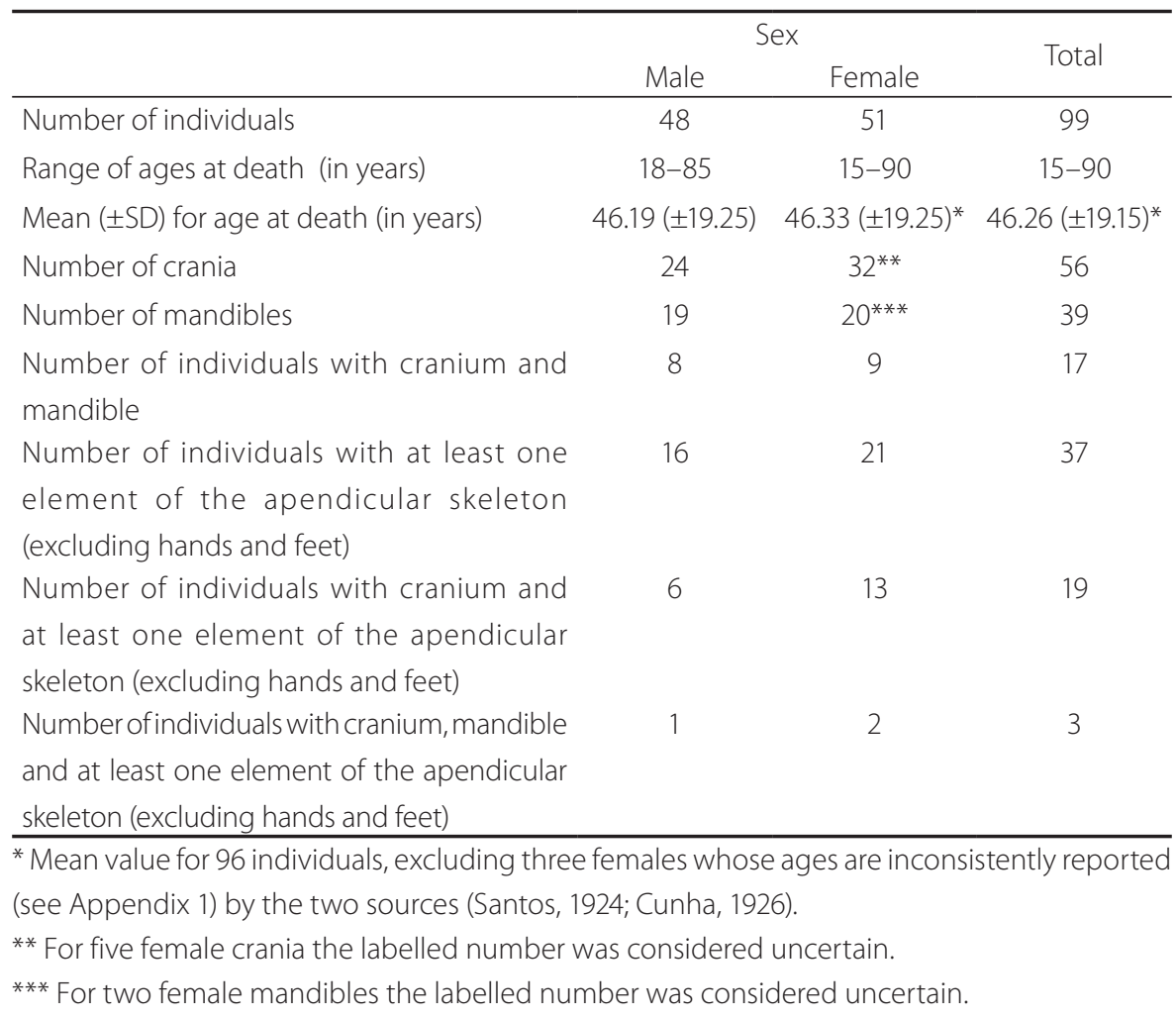


the skeletons collected by Mendes Correia came from several cemeteries of Porto. However, the only two references to the actual provenience of the remains (Correia, 1917b; Valença, 1925) mention

\section{Final remarks}

As a result of a thorough investigation of both written and oral sources of information, the Mendes Correia collection is now brought under a new light after almost a century of nearly anonymity. Although the original documentation is still unaccountable for, and a portion of the remains collected by Mendes Correia is now lost, our study has restored, at least partly, the research value of the surviving collection. Currently, the collection is stored at the NHM and FSUP where the remains are presently organized by bone type and not by individual. However, the bones of the same individual can be brought back together by using the collection number in the labels.

The Mendes Correia collection was amassed either at the same time as the similar cemetery collection in Coimbra or slightly later. Comparatively, however, the Mendes Correia Collection is much smaller, comprised of only about 40 complete skeletons (Correia, 1930) and over 100 skulls. The Coimbra Collection became much larger ( $n=505)$, and even the Ferraz de Macedo Collection is believed to be larger $(n=300)$. Despite its size, the Mendes Correia Collection has the intrinsic value of being the single osteological collection representative of the 19th century population of the Northern part of the country, and can perhaps now contribute to studies about cross-country variation together with the Lisbon and Coimbra collections.

Additionally, the Mendes Correia Collection has the potential to provide a source of information about secular changes through comparative studies with other more recent Portuguese collections. For example, in 2013 the BoneMedLeg team presented at the 12th National Meeting of Legal Medicine and Forensic Sciences in Porto, Portugal (Marinho et al., 2013), providing the results of a preliminary analysis of secular trend effects on sexual dimorphism. This study compared craniometric data between a sample of males and females in the Mendes Correia (individuals born roughly between 1820 and 1900) and in the BoneMedLeg (individuals born roughly between 1900 and 1990) collections, which are about one century apart. The results showed no significant 
secular changes in absolute size or sexual dimorphism in size over that one century, but a tendency for a decrease in sexual dimorphism was noted.

In order to enhance the research potential of the existing Mendes Correia Collection, it would be important to review its conservation status, rejoin it and properly organize, catalogue and curate it. Particularly, several of the specimens would benefit from improved storage and renewed labels. Perhaps even more information can be brought forward if other researchers find interest in the study of the Mendes Correia collection and carry out their own independent investigations. What is also crucial is that the collection should be made available to the wider scientific community and be used for the benefit of future generations of physical anthropologists. These are challenges that we are asking the NHM and the FSUP to take in the hopes that the Mendes Correia Collection will have, once more, a significant role among the Portuguese physical anthropology community.

\section{Acknowledgements}

The authors would like to thank Dr. Nuno Ferrand and Maria José Cunha for providing information and access to the collection in the Museum of Natural
History of the University of Porto. To Dr. Aires Oliva Teles and Dr. Silvia Cabral for providing information and access to the collection at the Faculty of Sciences. To Dr. Maria João Prata, António Huet Bacelar and Celeste Brandão for sharing their knowledge (or lack thereof) about the collection and its history.

\section{References}

Anselmo, D. P.; Fernandes, T. 2013. A possible case of hypertrophic pulmonary osteoarthropathy in an identified skeleton from the cemetery of Évora, Portugal: differential diagnosis. In: Malgosa, A.; Isidro, A.; Ibáñez-Gimeno, P.; Prats-Muñoz, G. (eds.) Vetera corpora morbo afflicta. Actas delXI Congreso Nacional de Paleopatología, October 2013. Barcelona, Universitat Autònoma de Barcelona: 63-76.

Bedford,M.E.;Russell, K. F.;Lovejoy, C.O.;Meindl, R. S.; Simpson, S. W.; Stuart-Macadam, P. L. 1993. Test of the multifactorial aging method using skeletons with known ages-at-death from the Grant collection. American Journal of Physical Anthropology, 91: 287-297. DOI: 10.1002/ajpa.1330910304.

Cardoso, H. F. V. 2006a. Elementos para a história da antropologia biológica em Portugal: o contributo do Museu Bocage (Museu Nacional de História Natural, Lisboa). Trabalhos de Antropologia e Etnologia, 46: 47-66. 
Cardoso, H. F. V. 2006b. Brief communication: the collection of identified human skeletons housed at the Bocage Museum (National Museum of Natural History), Lisbon, Portugal. American Journal of Physical Anthropology, 129: 173-176. DOI: 10.1002/ ajpa.20228.

Correia, A. A. M. 1917a. Osteometria Portuguesa: I coluna vertebral. Annaes Scientificos da Academia Polytechnica do Porto, XII: 227-254.

Correia, A. A. M. 1917b. Osteometria Portuguesa. Annaes Scientificos da Academia Polytechnica do Porto, XII: 225-226.

Correia, A. A. M. 1918a. Osteometria Portuguesa: Il cintura escapular. Annaes Scientificos da Academia Polytechnica do Porto, XIII: 102-123.

Correia, A. A. M. 1918b. Osteometria Portuguesa: II cintura escapular (continuação). Annaes Scientificos da Academia Polytechnica do Porto, XIII: 172-195.

Correia, A. A. M. 1920a. Osteometria Portuguesa: III cintura pélvica. Annaes Scientificos da Academia Polytechnica do Porto, XIV: 56-71.

Correia, A. A. M. 1920b. Osteometria Portuguesa: IV esqueleto do braço e do antebraço. Annaes Scientificos da Academia Polytechnica do Porto, XIV: 243-253.

Correia, A. A. M. 1927. Osteometria Portuguesa: IV esqueleto do braço e do antebraço (continuação). Annaes Scientificos da Academia Polytechnica do Porto, $\mathrm{XV}: 25-56$

Correia, A. A. M. 1930. Institut d'Anthropologie de la Faculté des Sciences de l'Université de Porto. In: Notice Sommaire. XV Congresso International d'Anthropologie et d'Archéologie Préhistorique: 1-38.

Cunha, A. J. 1926. Notas de camptometria nos crânios Portugueses. Doctoral dissertation, Faculty of Medicine, University of Porto.

Cunha, E.; Wasterlain, S. 2007. The Coimbra identified osteological collections. In: Grupe, G.; Peters, J. (eds.) Documenta Archaeobiologiae, 5. Skeletal Series and Their Socio-Economic Context. Rahden, Westfalen, Verlag Marie Leidorf: 23-33.

Cunha, M. J. 2012. As coleções de Arqueologia e Antropologia do Museu de História Natural da Universidade do Porto. Series de Investigación Iberoamericana en Museología [Online], 6: 153-162. [Accessed 22-3-2013]. Available at: http://www.uam.es/mikel.asensio.

Dayal, M. R.; Kegley, A. D. T.; Strkalj, G.; Bidmos, M. A.; Kuykendall, K. L. 2009. The history and composition of the Raymond $\mathrm{A}$. Dart Collection of human skeletons at University of the Witwatersrand, Johannesburg, South Africa. American Journal of Physical Anthropology, 140: 324-335. DOl: 10.1002/ajpa.21072.

Fernandes, A. S. 1925. Sôbre uma correlação anatómica nos crânios portugueses: estudo osteométrico. Doctoral dissertation, Medical School, University of Porto. 
Fernandes, M. T. M. 1985. Colecções osteológicas. In: Museu e Laboratório Antropológico da Universidade de Coimbra (ed.) Cem anos de antropologia em Coimbra, 1885-1985. Coimbra, Museu e Laboratório Antropológico: 77-81.

Ferreira, A. A. C. (ed.) 1908. O anthropologista Ferraz de Macedo: apontamentos para a história da sua vida e da sua obra. Lisbon, Typographia A Editora.

Ferreira, M. T.; Vicente, R.; Navega, D.; Gonçalves, D.; Curate, F.; Cunha, E. 2014. A new forensic collection housed at the University of Coimbra, Portugal: the 21st century identified skeletal collection. Forensic Science International, 245: 202.e1-202.e5. DOI: 10.1016/j.forsciint.2014.09.021.

Hunt, D. R.; Albanese, J. 2005. History and demographiccompositionoftheRobert J. Terry anatomical collection. American Journal of Physical Anthropology, 127: 406-417. DOl 10.1002/ajpa.20135.

Komar, D. A.; Grivas, C. 2008. Manufactured populations: what do contemporary reference skeletal collections represent? A comparative study using the Maxwell Museum documented collection. American Journal of Physical Anthropology, 137: 224-233. DOI: 10.1002/ajpa.20858.

Marado, L. M. 2010. Análise dos caracteres discretos da dentição inferior e do osso mandibular numa série do Museu de História Natural (FCUP). Master dissertation, Life Sciences Department,
Faculty of Sciences and Technology, University of Coimbra.

Marinho, L.; Cardoso, H. 2012. BoneMedLeg: two new collections of identified human skeletons being amassed in Porto, Portugal for forensic purposes. In: Gledhill, J. (ed.) Evolving Humanity, Emerging Worlds. Conference Program of the 17th World Congress of the International Union of Anthropological and Ethnological Sciences, Manchester, 5th-10th August 2013. Manchester, International Union of Anthropological and Ethnological Sciences: 195.

Marinho, L.; Toso, A.; Assis, S.; Puentes, K.; Abrantes, J.; Santos, A.; Magalhães, T.; Caldas, I.; Andrade, M.; Pinto da Costa, D.; Cardoso, H. 2013. Secular changes on the sexual dimorphism of adult crania in two Portuguese modern collections: a comparative analysis and potential forensic implications [in Portuguese]. 2013. [Online]. [Porto], ResearchGate. [Accessed on 21-04-2016]. Available at: https://www.researchgate. net/publication/301552989_ Secular_changes_on_the_sexual_ dimorphism_of_adult_crania_ in_two_Portuguese_modern_ collections_A_comparative_analysis_ and_potential_forensic_implications_ in_Portuguese.

Matos, P. C. V. F. 2012. Mendes Correia e a escola de antropologia do Porto: contribuição para o estudo das relações entre antropologia, nacionalismo $e$ colonialismo (de finais do século XIX 
aos finais da década de 50 do século $X X$ ). Doctoral dissertation, Instituto de Ciências Sociais, University of Lisbon.

Passalacqua, N. V. 2009. Forensic age-at-death estimation from the human sacrum. Journal offorensic Sciences, 54: 255-262. DOI: 10.1111/j.1556-4029.2008.00977.x.

Rocha, M. A. 1995. Les collections ostéologiques humaines identifiés du musée anthropologique de l'université de Coimbra. Antropologia Portuguesa, 13: 7-38.

Santos, A. L. 2000. A skeletal picture of tuberculosis. Macroscopic, radiological, biomolecular, and historical evidence from the Coimbra Identified Skeletal Collection. Doctoral dissertation, Anthropology Department, University of Coimbra.

Santos, G. 2012. The birth of physical anthropology in Late Imperial Portugal. Current Anthropology, 53(S5): S33-S45. DOI: $10.1086 / 662329$.

Santos, M. A. C. S. C. 1924. O ângulo facial nos crânios Portugueses. Doctoral dissertation, Faculty of Medicine, University of Porto.

Santos Júnior, J. R. 1969. O Professor Mendes Correia, fundador e $2 .^{\circ}$ presidente da Sociedade Portuguesa de Antropologia e Etnologia. Trabalhos de Antropologiae Etnologia da Sociedade Portuguesa de Antropologia e Etnologia, XXI: 37-45.

Teixeira, C. 1964. Elogio histórico de A. A. Mendes Correia. Memórias da Academia das Ciências de Lisboa, I: 47-66.
Umbelino C.; Santos, A. L. 2011. Portugal. In: Márquez-Grant, N.; Fibiger, L. (eds.) The Routledge handbook of archaeological human remains and legislation: an international guide to laws and practice in the excavation and treatment of archaeological human remains. London, Routledge: 341-352.

Usher, B. M. 2002. Reference samples: the first step in linking biology and age in the human sekeleton. In: Hoppa, R. D.; Vaupel, J. W. (eds.) Paleodemography: Age Distributions from Skeletal Samples. New York, Cambridge University Press: 29-47.

Valença, E. 1925. A fronte nos portugueses: estudo craniométrico. Doctoral dissertation, Faculty of Medicine, University of Porto. 


\section{Appendix 1.}

Inventory of the skeletons currently belonging to the Mendes Correia collection with known sex, age and nativity (from Santos, 1924 and Cunha, 1926). The presence of cranium and mandible for each individual is also provided. Columns labeled as appendicular (\#) and post-cranium (\#) show the number of single complete bones identified for each individual (note: number of bones per individual may be underestimated due to failure to recognize the collection number in some specimens).

\begin{tabular}{|c|c|c|c|c|c|c|c|}
\hline $\begin{array}{c}\text { Coll. } \\
\#\end{array}$ & Sex & $\begin{array}{c}\text { Age } \\
\text { (years) }\end{array}$ & Nativity & Cranium & Mandible & $\begin{array}{c}\text { Appendicular } \\
(\#)\end{array}$ & $\begin{array}{c}\text { Post } \\
\text { cranium(\#) }\end{array}$ \\
\hline 1 & Female & 36 & Gaia & Present & Dubious** & 8 & 4 \\
\hline 2 & Female & 60 & Penafiel & Present & - & 5 & 7 \\
\hline 3 & Male & 54 & Braga & Present & - & 3 & - \\
\hline 4 & Female & 61 & Porto & Present & - & 6 & 4 \\
\hline 5 & Female & 60 & Porto & Dubious** & - & 6 & 5 \\
\hline 8 & Female & 29 & $\begin{array}{c}\text { Sobrado de } \\
\text { Paiva }\end{array}$ & Present & - & 5 & 2 \\
\hline 9 & Female & 64 & Porto & Dubious** & - & 5 & 4 \\
\hline 10 & Male & 44 & Amarante & - & - & 7 & 7 \\
\hline 11 & Male & 47 & Porto & Present & - & 4 & 2 \\
\hline 12 & Female & 22 & Taboaço & Present & - & 3 & - \\
\hline 13 & Male & 50 & - & Present & - & 5 & - \\
\hline 14 & Female & 29 & Porto & - & - & 4 & 2 \\
\hline 15 & Female & 26 & Porto & - & - & 8 & 4 \\
\hline 16 & Female & 24 & Porto & - & Dubious** & 6 & - \\
\hline 17 & Female & $84 / 48^{*}$ & $\begin{array}{l}\text { Castelo de } \\
\text { Paiva }\end{array}$ & Present & Present & 9 & 7 \\
\hline 18 & Female & 80 & - & Present & - & - & - \\
\hline 19 & Female & 33 & Tondela & Present & - & 6 & 1 \\
\hline 21 & Female & 79 & - & - & - & 2 & 1 \\
\hline 22 & Female & $39 / 29^{*}$ & Braga & - & - & 7 & 13 \\
\hline 23 & Male & 56 & Lamego & - & Present & 8 & 11 \\
\hline 24 & Female & 60 & - & Present & - & 2 & 5 \\
\hline 25 & Male & 25 & Baião & - & - & 7 & 30 \\
\hline 26 & Female & 38 & $\begin{array}{l}\text { S. Vicente de } \\
\text { Campo }\end{array}$ & - & - & 1 & - \\
\hline 27 & Female & 90 & - & Present & - & 6 & 1 \\
\hline
\end{tabular}




\begin{tabular}{|c|c|c|c|c|c|c|c|}
\hline $\begin{array}{c}\text { Coll. } \\
\# \\
\end{array}$ & Sex & $\begin{array}{c}\text { Age } \\
\text { (years) }\end{array}$ & Nativity & Cranium & Mandible & $\begin{array}{c}\text { Appendicular } \\
(\#) \\
\end{array}$ & $\begin{array}{c}\text { Post } \\
\text { cranium(\#) }\end{array}$ \\
\hline 29 & Male & 35 & Porto & Present & - & 5 & - \\
\hline 30 & Female & 15 & - & Present & - & 3 & 4 \\
\hline 35 & Female & 23 & Lamego & Present & - & 5 & 3 \\
\hline 36 & Female & 81 & - & Present & Present & 1 & 1 \\
\hline 37 & Male & 42 & Canaveses & - & - & 8 & 5 \\
\hline 38 & Male & 28 & $\begin{array}{l}\text { Carrazeda } \\
\text { de Anciães }\end{array}$ & - & - & 4 & 5 \\
\hline 39 & Male & 47 & Vila da Feira & - & Present & 4 & 9 \\
\hline 40 & Male & 42 & Aveiro & Present & Present & 4 & 2 \\
\hline 41 & Male & 27 & Porto & - & Present & 1 & - \\
\hline 42 & Male & 18 & Porto & Present & - & - & - \\
\hline 43 & Female & 30 & Porto & Present & - & - & - \\
\hline 44 & Male & 75 & - & - & - & - & - \\
\hline 45 & Female & 60 & - & Present & Present & - & - \\
\hline 46 & Female & 70 & Porto & - & - & - & - \\
\hline 48 & Female & 50 & - & Present & - & - & - \\
\hline 50 & Male & 30 & Porto & Present & - & - & - \\
\hline 51 & Male & 24 & Santo Tirso & - & Present & - & - \\
\hline 52 & Female & 65 & - & Present & Present & - & - \\
\hline 53 & Female & 71 & Minho & - & Present & - & - \\
\hline 55 & Male & 24 & Porto & Present & - & - & - \\
\hline 58 & Male & 85 & Porto & Present & - & - & - \\
\hline 59 & Male & 40 & Armamar & - & - & - & - \\
\hline 60 & Male & 40 & Armamar & Present & Present & - & - \\
\hline 61 & Male & 18 & Porto & - & - & - & - \\
\hline 62 & Male & 18 & Porto & - & Present & - & - \\
\hline 63 & Male & 35 & Porto & - & - & - & - \\
\hline 64 & Male & 21 & Amarante & Present & - & - & - \\
\hline 65 & Male & 60 & - & - & - & - & - \\
\hline 66 & Male & 26 & Rezende & - & Present & - & - \\
\hline 67 & Male & 47 & Porto & Present & - & - & - \\
\hline 68 & Female & 30 & Foscôa & - & Present & - & - \\
\hline 70 & Female & 42 & - & Present & - & - & - \\
\hline 71 & Male & 42 & Paredes & - & - & - & - \\
\hline
\end{tabular}




\begin{tabular}{|c|c|c|c|c|c|c|c|}
\hline $\begin{array}{c}\text { Coll. } \\
\#\end{array}$ & Sex & $\begin{array}{c}\text { Age } \\
\text { (years) }\end{array}$ & Nativity & Cranium & Mandible & $\begin{array}{c}\text { Appendicular } \\
(\#)\end{array}$ & $\begin{array}{c}\text { Post } \\
\text { cranium(\#) }\end{array}$ \\
\hline 73 & Male & 62 & $\begin{array}{l}\text { Castelo de } \\
\text { Paiva }\end{array}$ & - & - & - & - \\
\hline 74 & Male & 28 & Porto & Present & Present & - & - \\
\hline 75 & Male & 36 & $\begin{array}{l}\text { Vila do } \\
\text { Conde }\end{array}$ & - & Present & - & - \\
\hline 77 & Male & 77 & - & - & Present & - & 1 \\
\hline 78 & Male & 60 & Chaves & Present & - & - & - \\
\hline 79 & Female & $112 / ?^{*}$ & Arouca & Present & Present & - & - \\
\hline 80 & Female & 47 & Porto & Present & Present & - & - \\
\hline 81 & Female & 47 & - & - & Present & - & - \\
\hline 82 & Female & 30 & $\begin{array}{c}\text { Miranda do } \\
\text { Douro }\end{array}$ & - & Present & - & - \\
\hline 83 & Male & 67 & - & Present & Present & - & - \\
\hline 85 & Female & 38 & Porto & - & Present & - & - \\
\hline 86 & Male & 26 & $\begin{array}{l}\text { Ribeira de } \\
\text { Pena }\end{array}$ & - & - & - & - \\
\hline 87 & Female & 40 & Gaia & Dubious** & Present & - & - \\
\hline 88 & Female & 36 & Porto & Present & - & - & - \\
\hline 90 & Female & 50 & $\begin{array}{l}\text { Vila Pouca } \\
\text { d'Aguiar }\end{array}$ & - & - & - & - \\
\hline 93 & Male & 40 & Porto & Present & - & - & - \\
\hline 94 & Female & 81 & $\begin{array}{l}\text { Oliveira de } \\
\text { Azemeis }\end{array}$ & Present & - & 1 & - \\
\hline 96 & Male & 84 & - & Present & Present & - & - \\
\hline 97 & Female & 37 & Porto & Dubious** & - & - & - \\
\hline 98 & Female & 48 & Penafiel & - & - & - & - \\
\hline 99 & Female & 37 & Valbom & - & - & - & - \\
\hline 100 & Male & 55 & Penafiel & Present & - & - & - \\
\hline 102 & Male & 65 & Lamego & Present & - & - & - \\
\hline 103 & Female & 39 & Penafiel & - & Present & - & - \\
\hline 104 & Female & 36 & Porto & Present & Present & - & - \\
\hline 105 & Female & 41 & Penafiel & Present & - & - & - \\
\hline 106 & Male & 76 & - & - & Present & - & - \\
\hline 107 & Male & 66 & Porto & Present & Present & - & - \\
\hline 108 & Female & 64 & Bragança & Present & Present & - & - \\
\hline 110 & Female & 26 & Porto & Dubious** & Present & - & - \\
\hline
\end{tabular}




\begin{tabular}{cccccccc}
\hline $\begin{array}{c}\text { Coll. } \\
\#\end{array}$ & Sex & $\begin{array}{c}\text { Age } \\
\text { (years) }\end{array}$ & Nativity & Cranium & Mandible & $\begin{array}{c}\text { Appendicular } \\
(\#)\end{array}$ & $\begin{array}{c}\text { Post } \\
\text { cranium(\#) }\end{array}$ \\
\hline 111 & Female & 37 & Braga & - & - & - & - \\
112 & Female & 49 & Porto & Present & - & - & - \\
113 & Female & 15 & - & Present & Present & - & - \\
114 & Male & 75 & S. Pedro do & Present & Present & - & 1 \\
116 & Male & 49 & Braga & Present & Present & - & - \\
117 & Female & 28 & Amarante & - & Present & - & - \\
118 & Male & 70 & Castelo & Present & - & - & - \\
121 & Female & 70 & - & - & - & - & 1 \\
122 & Male & 33 & Porto & - & Present & 7 & 31 \\
123 & Male & 27 & Porto & - & Present & 1 & 1 \\
124 & Male & 73 & Tondela & - & - & 7 & 20 \\
125 & Male & 48 & Porto & Present & - & 8 & 18 \\
\hline
\end{tabular}

* The age of each individual, as indicated by the two sources (Santos, 1924; Cunha, 1926), is inconsistent, as shown.

** The collection number written on the crania or mandible had faded away partially and the attribution of the remains to that specific collection number was considered uncertain. 